\title{
COLLEGIAL PUBLIC ADMINISTRATIVE SUBJECTS IN ADMINISTRATIVE LEGAL PROCEEDINGS AS PARTIES TO A CASE (A PLAINTIFF, A DEFENDANT, AND THE THIRD PERSON)
}

\section{Tsvirkun Yu. I.}

The law for people has been always a certain order in society ${ }^{1}$ which always required security and protection. Taking into account this law of social reality, it is unacceptable for society to have no efficiently justified and developed legal mechanisms to appeal against unlawful actions of a collegial public administration subject as well as their opportunity to appeal against offenders. However, these subjects could not be plaintiffs or take part in administrative proceedings in any other way during both post-soviet period of Ukrainian legal system development and before the adoption of the Constitution of Ukraine on June 28, 1996, where Article 55 provided the right to appeal to a court against decisions, acts or inaction of state authorities, self-government bodies, officials and officers, and Article 124, part 2 stipulated that court jurisdiction covered all legal relations arose in Ukraine. The period of 1997-2004 is characterized by researchers as such period, during which it was not possible to achieve the expected progress in the implementation of administrative reform ${ }^{2}$. Thus, during the period from 1996 to 2005, these opportunities regarding the collegial public administration subject were more illusory than real, and since 2006 to the present, the participation of these subjects in cases in administrative proceedings has been slowly tested on the basis of not yet thoroughly comprehensible issue at the level legal doctrine. Moreover, we should take into account that the model of administrative justice that is typical of the Romano-Germanic legal system, implemented within the framework of a separate organizational structure of specialized courts and relevant procedural legislation, reveals problems of efficiency in Ukraine, following from the evaluation of the prevailing dissatisfaction of

\footnotetext{
1 Лившиц Р. 3. Теория права. Учебник М.: Издательство БЕК, 1994. С. 11.

2 Європейські оріснтири адміністративного реформування в Україні : монографія / за заг. ред. В. Д. Бакуменка, В. М. Князєва. К. : Вид-во НАДУ, 2005. С. 1.
} 
population with the activity of courts as $\mathrm{such}^{3}$, in our case, according to the criteria for administrative court availability, the level of public trust in the administrative court, professionalism of judges and employees in the court apparatus ${ }^{4}$. On this background, the issue of justice of decisions in cases involving collegial public administration subjects requires a clear definition of key concepts and elements of status of these subjects.

The legal nature of the administrative law subject manifests itself in its special properties. The administrative law subject is different from other elements of the administrative law system in the fact that it is a carrier of interrelated qualities, namely external isolation; personalization; the will, determined in administrative legal capacity; administrative legal regulation. The presence of such features in a particular subject allows noting that this subject is an administrative law subject, functioning in its system as an element and a carrier of rights and obligations. In turn, administrative law acts as an area of potential and actual interrelations and interaction of administrative law subjects, outside of which there is no its subjects ${ }^{5}$. Through the application of legal tools in overcoming economic and other social problems, they achieve the effect of realizing social value, the power of law, and their mission to be a stabilizing factor, ensuring, in particular: a) reliability and stability of relations; b) correlation of regulation with subjective rights; c) strict regulation and, at the same time, guarantee and protection of subjective rights; d) a set of way, in our case, a collegial way of decision-making that guarantees real, actual performance of legal obligations; e) the necessary procedure for implementation of legal actions, procedural forms and mechanisms aimed at the exercise of subjective rights and the achievement of truth in conflict situations ${ }^{6}$.

As S. P. Pogrebnyak and M. I. Kozyubra have rightly emphasized, the subject is not something amorphous, non-personal. The subjects of the legal relations are (finally) always people who create the right to ensure normal life and exercise it, being in different statuses: an ordinary citizen,

\footnotetext{
3 Довіра до суду та імідж судової влади: які вони сьогодні? / дата звернення 10.05.2018. URL : https://censor.net.ua/blogs/3065355/dovra_do_sudu

${ }^{4}$ Іванченко О. Система критеріїв оцінювання ефективності діяльності судів під час надання судових послуг. Підприємництво, господарство і право. 2017. № 11. С. 224.

5 Мацелик Т. О. Суб'єкти адміністративного права: поняття та система: монографія. Ірпінь: Вид-во Нац. ун-ту ДПСУ, 2013. С. 82.

${ }^{6}$ Алексеев С. С. Теория права. М.: Издательство БЕК, 1995. С. 223.
} 
a public official, association of people or community, etc. ${ }^{7}$. And if a person has subjective rights and obligations, even if he or she can not perform the first or observe the latter, then the legal entity as a collective, abstract (fictitious) subject works through its bodies, taking actions, including unlawful ones, only through the natural persons from whom it is composed. In this case, the morality of acts of such natural persons is evaluated on the basis of their corporate belonging to the collective entity $^{8}$, one of the specific manifestations of management of which, along with undivided authority, is collegiality.

The subjects of public authority namely, state power bodies, local self-government bodies, their officials, etc. are considered the typical subjects of relations in public law ${ }^{9}$, as well as, following Yu. L. Paneiko, V. M. Bevzenko, G. V. Panova and others, non-state subjects with delegated powers from public authorities, for example, a private notary, an advocate etc. ${ }^{10}{ }^{11}$. As previously emphasized, public administration in administrative law of European countries is defined in most cases as a set of bodies and institutions implementing public authority through the implementation of law, by-laws and other actions in the public interest, that is, the system of organizational and structural entities that have acquired authority on legitimate grounds for satisfying such interests ${ }^{12}$ in the area of intensive legal regulation, that is, beyond the private law fields, with the widespread use of dense normative means, in particular imperative norms, which clearly and exhaustively outline the powers of each, as well as legally effective forms of solving typical life problems and specific legal means of the operational level ${ }^{13}$. Public legal relations are based on subordination of subjects and express a centralized system of regulation, where common social interest, as a rule, is a priority ${ }^{14}$.

\footnotetext{
7 Загальна теорія права: підручник / За заг. ред. М.І. Козюбри. К.: Ваіте, 2015. С. 228.

${ }^{8}$ Máynez E. G. Introduccion al estudio del derecho : libro didáctico. - 53 Edición. México : Editorial Porrua, 2002. C. 279-280.

9 Загальна теорія права: підручник / За заг. ред. М.І. Козюбри. К.: Ваіте, 2015. С. 230.

${ }^{10}$ Бевзенко В. М., Панова Г. В. Сутність та підстави втручання адміністративного суду у розсуд суб'єкта публічної адміністрації: монографія. К. : ВД «Дакор», 2018. С. 1-2.

${ }^{11}$ Панейко Ю. Л. Наука адміністрації й адміністративного права (загальна частина). Т. 1. Аугсбург, 1949. С. $107-112$

12 Колпаков В. К. Адміністративно-правові відносини: поняття і види. Юридичний науковий електронний журнал. 2013. № 1. С. 102.

13 Алексеев С. С. Теория права. М.: Издательство БЕК, 1995. С. 215, 219.

${ }^{14}$ Петров А. В., Баукен А. А. Теория государства и права: учебное пособие. Челябинск : Издат. центр ЮУрГУ, 2014. С. 132.
} 
According to the criterion of the officials' number, exercising professional legal capacity, the public administration subjects are divided into individual and collegial subjects, including in the field of public administration. Branch legal capacity is defined by the branch of legislation that acts in relation to the person and, this way, specifies the range of legal relations in which a person can participate ${ }^{15}$. At the same time, T.O. Matselik rightly emphasized that such legal capacity is a potential ability (power) of a person to have and exercise rights and obligations in the field of public administration (administrative legal capacity and legal ability, respectively), but not legal capacity as such, but its administrative-legal type within the limits of the competence specified in law, exercised through the public authority of the subject independently in organizational and functional terms. In this case, the collegial public administration subjects and other collective subjects of administrative law are characterized by the fact that their social will is different from the will of certain persons who are members of their composition, and therefore they can be independent carriers of rights that belong to them only as a whole ${ }^{16}$.

The collegium (from the Latin collegium - community, union, and collaboration) is a group of people. Collegiality is the form (principle) of the organizational structure of the public administration/public administration subjects provides, first of all, that it is governed by more than one official who jointly and within the powers generalized by the competence defined by laws, form and approve decisions/actions (including on the basis of the decisions approved). Such community of acts/decisions leads to the question of a quorum which is sufficient for legitimization of activity, as well as higher responsibility, comparing to the sole subjects of public administration, as a consequence of the will objectification of more than one person. This joint energy potential of the will and responsibility guarantees the quality of legal regulation in the form of decisions based on taking into account more/or all significant factors, including historically and socially justified interests of people, thus showing signs of democratic governance. At the same time, the intensity of such legal influence and regulation becomes a derivative of

\footnotetext{
${ }^{15}$ Алексеев С.С. Общая теория права : учеб. 2-е изд., перераб.и доп. М. : ТК Велби, Изд-во Проспект, 2008. С. 380.

${ }^{16}$ Мацелик Т. О. Суб’єкти адміністративного права: поняття та система: монографія. Ірпінь: Вид-во Нац. ун-ту ДПСУ, 2013. С. 81.
} 
the mass of interests having received their legal mediation, and reflects its growth and enrichment of the structure of interests ${ }^{17}$, in accordance with the permanent complication of social relations.

For completeness of the described facets of "collegiality" as a quality of the public administration subject, we take into account the manifestations of the phenomena of individual and collective legal consciousness and legal culture, which are revealed on the basis of legal regularity well-defined by S. S. Alekseev, namely: the quality of social environment, peculiarities of the "area", its energy orientation largely influences the construction of legal regulation, the effectiveness of regulation systems used during legal influence, in particular the systems of "duty - responsibility" or "rights - guarantees". For the subjects studied by us it is typical that the legal energy, which comes to the area of legal reality from above, from state bodies ${ }^{18}$ is multiplied by social capital (knowledge, abilities, skills, etc.) of not one official, but their group.

Collegial bodies in their organizational structure are such bodies that solve complex issues of economic, socio-cultural and administrativepolitical construction at the respective territory and coordinate work in different $\operatorname{areas}^{19}$. In collegial bodies, administrative acts are usually adopted through discussion and subsequent voting and signing by all members of this body or only by the chairman of its meeting (hearing) and secretary ${ }^{20}$. The collegial structure of public administration bodies is expressed in the fact that the body itself is a collegium or that the body is headed by a group of persons (collegium), in particular, they have the highest decision-making authority in its composition, a board composed of several members of the highest units of such a body, and/or managers of its lower levels (structural units), organized in accordance with the principles of hierarchy and subordination ${ }^{21}$. Accordingly, collegiality as a form of organizational structure of collegial public administration subjects is expressed in the presence of group/collegial management bodies.

\footnotetext{
${ }^{17}$ Шайкенов Н.А. Правовое обеспечение интересов личности. Свердловск: Изд-во Урал. ун-та, 1990. C. 87.

${ }^{18}$ Алексеев С. С. Теория права. М.: Издательство БЕК, 1995. С. 213, 224.

${ }^{19}$ Алексеев С.С. Общая теория права : учеб. 2-е изд., перераб.и доп. М. : ТК Велби, Изд-во Проспект, 2008. C. 4, 6 .

${ }^{20}$ Галунько В., Діхтієвський П., Кузьменко О., Стеценко С. та ін. Адміністративне право України. Повний курс: Підручник. Херсон: Олді-плюс, 2018. С. 164.

${ }^{21}$ Давитнидзе И. Л. Коллегиальность и единоначалие в советском государственном управлении. М. : «Знание», 1974. С. 5.
} 
Collegial bodies of public authority are characterized by certain "autonomy" of the body apparatus from collegial body members, except its head. These bodies consist of officials who are legally recognized as equal (Parliament, Constitutional Court, CEC, etc.) in the sense that within these bodies there is no official subordination between the body members and the person who heads (is the leader of) a collegial body (in separate exceptions - for example, the government). Not all members, but only the head of such body (and managers of existing structural units in it, for example, parliamentary committees) has the status of a subject of authority by exercising power management functions in relation to the apparatus of the collegial body (or the units of its structural subdivisions).

In the collegial bodies of public authority, the relations of public service arise provided that the body includes either public political entities (for example, the government) or persons who are vested with the status of civil servants (for example, the Accounting Chamber, the CEC, the Antimonopoly Committee). This way, the members of such bodies in internal organizational relations are the carriers of not the general legal status of a citizen (a natural person), but of a special legal status due to the entry into the collegial body to which the relevant persons are elected (for example, members of parliament) or appointed (for example, members of the High Council of Justice). At the same time, the Code of Administrative Legal Proceedings of Ukraine on July 6, 2005 (hereinafter - CAP) ensures the possibility to appear in the administrative court as a plaintiff on public service issues for persons with a special status if they, as members of a collegial body, occupy state political positions, are in state or other public service ${ }^{22}$. Collegiality for a collegial public administration subject is an organizational legal form (principle) of the public administration activities ${ }^{23}$. Therefore, we join the opinion that the main difference between the structure of administrative and legal status of individual and collective subjects of law is that the latter have more complex legal status, associated with the peculiarities of their formation and functioning. In particular, administrative-legal status of collective subjects of law also includes administrative competence, that is,

\footnotetext{
22 Авер'янов В. Понятійно-термінологічні новели кодексу адміністративного судочинства України: дискусійні проблеми. Право України. 2011. № 4. С. 32.

${ }_{23}$ Давитнидзе И. Л. Коллегиальность и единоначалие в советском государственном управлении. М. : «Знание», 1974. С. 7.
} 
the legislatively established scope of powers of such subject ${ }^{24}$, its legal capacity, specified in the rights and obligations that constitute a single whole for officials of the subject of authority and show the same nature of a common compulsory rule which must be observed ${ }^{25}$.

Thus, the substance of the collegiality phenomenon in relation to the public administration subject is represented as a way of its activity. It acts or avoids action through the use of a set of means, techniques and methods that reveal the involvement of several (more than one) natural persons in it. They prepare, discuss and take all other actions necessary for the appearance and implementation of the decision together. The material and legal nature of the collegial public administration subject is determined by means of administrative law through the definition of its features as a state and municipal subject of power, which carries out organizational and administrative activities aimed at the preparation and implementation of management decisions, the provision of services to population, etc., in the form of collective/group work, or a non-state subject with the powers delegated from the public administration subject with the appropriate nature and form of implementation. The implementation of such potential in the composition of participants to cases in administrative proceedings involves referring to relevant norms of the procedural content, determining the procedural and legal status of the collegial public administration subject.

The branch legal status of a subject in the field of administrative law should be considered as the most important and most fundamental part of the general legal status. The rights and obligations are specified taking into account the branch legal capacity in the administrative-legal status in a generalized form. It is considered in conjunction with implementation of rights and freedoms, competences in the field of public administration, as well as implementation of obligations assigned to the subject ${ }^{26}$. Administrative-legal status covers a set of specially defined subjective rights and obligations, enshrined in the relevant subject of administrative law norms. So, the necessary feature of acquiring an administrative-legal status by a person is the presence of specific subjective rights and

\footnotetext{
${ }^{24}$ Мацелик Т. О. Суб’єкти адміністративного права: поняття та система: монографія. Ірпінь: Вид-во Нац. ун-ту ДПСУ, 2013. С. 97.

${ }^{25}$ Явич Л. С. Общая теория права. Л.: Изд-во ЛГУ, 1976. С. 94.

26 Мацелик Т. О. Суб'єкти адміністративного права: поняття та система: монографія. Ірпінь: Вид-во Нац. ун-ту ДПСУ, 2013. С. 126.
} 
responsibilities in a person that are implemented by this person both in administrative legal relations and outside of them ${ }^{27}$, and in any case are aimed at realizing the democratic essence of the state, since the state does not govern its citizens, but created for citizens, provides them services, conditions for the full exercise of their rights and freedoms, protects their interests ${ }^{28}$.

As V. M. Bevzenko rightly emphasized, updated on October 03, 2017, the CAP preserves in general the approach to definition of the subject of authority that existed before, and at the same time, in clauses 9 , 10, and 12 of Article 19 of the CAP provides three new categories of subjects that were previously distinguished only at the level of judicial practice (state border guard institutions, attestation and other expert commissions). Some subjects of authority (or persons equated with such subjects) are provided by other articles of the CAP $(27,28,151,266$, and 267). However, certain conflict issues were left behind the attention of a lawmaker. For example, the legal status of advocate self-government bodies, the Audit Chamber of Ukraine and the Public Council of Integrity remained uncertain. The scientist suggested that the judges should be guided by four features by which one can check that one or another subject belongs to the subjects of authority: 1) the subject must act solely on the basis, within the limits and in the manner prescribed by law; 2) the possibility of adopting an administrative act; 3) implementation of administrative authority at the same time; 4) the limited implementation of powers by administrative and legal relations. As for classification of these subjects, the judge proposed to distinguish three groups of subjects: 1) with the status of a legal entity: state authorities, state bodies; 2) collective entities without the status of a legal entity: MSEC, departments of the State Border Guard Service of Ukraine; 3) individual subjects: officials and officers ${ }^{29}$, among which only the bodies of the first group may be collegial public administration subjects.

\footnotetext{
27 Авер'янов В. Б. Адміністративне право України. Академічний курс : в двох томах. К.: ТОВ «Видавництво «Юридична думка», 2007. Том 1: Загальна частина: підручник / гол. ред. кол. : Авер'янов В. Б. С. 194.

${ }^{28}$ Самагальська Ю. Я. Інспекційні повноваження та правові основи їх реалізації. Вісник Львівського ун-ту. Серія юридична. 2012. Вип. 56. С. 209.

${ }^{29}$ Українське право: Новий Кодекс адміністративного судочинства: позиція суддів Верховного Суду з проблемних питань / дата звернення 29.01.2018. URL: http://www.vaas.gov.ua/news/ukra\%D1\%97nskepravo-novij-kodeks-administrativnogo-sudochinstva-poziciya-suddiv-verxovnogo-sudu-z-problemnix-pitan/
} 
So, we have as the result that collegial public administration subjects may or may not have a status of legal entity. Establishing the legal status is one of the forms of legal regulation of a subject's activity. Legal status is a complex legal structure that allows characterizing the legal position of a particular person (a group of persons); defines their place in the system of administrative law subjects, consolidates their rights and obligations ${ }^{30}$, their guarantees, liability and other elements. Considering the structure of subject's legal status, it is necessary to distinguish between two types of subjects: individual and collective. The difference between these subjects predetermines the features and structure of their legal status. In particular, subjects are divided into individual (citizens, foreigners, stateless persons) and collective in administrative law, which, in turn, are divided into governmental and non-governmental organizations ${ }^{31}$. In the case of collegial public administration subjects, we add to the existing elements of the legal status definition - public-law functional orientation and collegiality - the elements of the status of a legal entity or its derivative elements of the status of collegial public administration subject operating on the basis of a legal entity or several legal entities, but did not obtain such signs itself.

Definition of the concept of "a collegial public administration subject as a party to a case in administrative proceedings" acquires the completeness through a combination of its abovementioned material and legal features with elements of procedural and legal status. As the scientists rightly emphasize, the status of the subject of authority in connection with its entry into the administrative process acquires different forms: the status of the parties, third persons, bodies authorized in court to protect the rights, freedoms and interests of other persons ${ }^{32}$. Cognition of the legal status in the administrative procedural body of the collegial public administration subject involves taking into account what it consists of as a real fact of the surrounding reality, which reveals at least two hypostases: administration and evaluation of administration in court. The substance of the first one in the legal field will remain uncertain even roughly, since in general it belongs to the subjective side of society life

\footnotetext{
${ }^{30}$ Мацелик Т. О. Суб’єкти адміністративного права: поняття та система: монографія. Ірпінь: Вид-во Нац. ун-ту ДПСУ, 2013. С. 97.

31 Ведерніков Ю. А., Шкарупа В. К. Адміністративне право України: навчальний посібник. К. : Центр навчальної літератури, 2005. С. 41.

32 Бевзенко В.М. Суб'єкти владних повноважень у адміністративному процесі України. Журнал східноєвропейського права. 2013. № 1. С. 17.
} 
(legal culture and its elements), objectifying the real facts of subjectiveobjective reality, expressed in the plurality of actions of the complainant and the respondent, becoming the actual grounds of the claim and objections to it. The only static fragments of the phenomenon studied by us are limited by establishment of the fact of use of a collegial method of right exercise, the listing of public administration subjects that are organizationally suitable for the application of such method, and by the outline of their competence. And all these elements do not add anything special to the procedural status of these subjects in administrative proceedings. The substance of the second one (administration judicial assessments) is an unstable field of judicial practice, possibly stabilized by decisions in example cases.

As a party to a case in administrative proceedings, the collegial public administration subject adds to its signs (public authorities in the field of management, collegiality of decision-making and responsibility for their implementation, etc.) some features that are determined by nature of the judicial administrative process. In fact, its material legal feature of administrative responsibility unfolds in dynamics of procedures under the current CAP. In the case, this subject does not perform any public authority functions (administrative- regulatory, administrative-procedural, administrative-jurisdictional, administrative-delinquent and/or etc.), but is solely based on the principles of dispositiveness and equality in relation to other participants to the case as a complainant, respondent, third person and/or person of other administrative-procedural nature within the current CAP.

Therefore, the mechanics of initiating the protection of public interests, and often the state position, the responses to claims through objections and justification of their decisions and acts, etc., becomes the main functional load of the concept of "a collegial public administration subject as a party to a case in administrative proceedings". In this approach, it becomes a decisive feature of the definition studied.

There is no definition of "parties to the case" in the CAP. Scientists reasonably describe that a party to administrative legal proceedings (administrative court proceedings) is a person vested with procedural rights and obligations by the current legislation of Ukraine in the area of administrative cases by administrative courts and who initiates the administrative process to protect their rights and legitimate interests, 
protection of rights and the legitimate interests of others, or in order to facilitate the administrative process implementation. Thus, it is the person who has a legal capacity and can perform procedural actions aimed at achieving the goal of the process, at least in one of the administrative process stages ${ }^{33}$. Both consideration and resolution of a dispute with the participation of the subject of authority in an administrative court are necessarily preceded by legal relations, regulated by the norms of substantial public law and are characterized by collisions of subjective legal interests, the presence of a dispute regarding the mutual distribution of rights and obligations between the natural person (legal entity) and the subject of authority ${ }^{34}$.

According to the CAP, identification of a collegial public administration collective as a party to a case under the rules of administrative proceedings takes place through its comparison with the list of those persons listed in Article 42, namely: it is indicated that the parties to the case are parties, third persons; the bodies and persons authorized by law to apply to the court in the interests of other persons may also participate in cases. For example, a claim for recognition of an unlawful legal act of a local council (respondent) "On granting a permit for the use of land for placement of stationary trade objects" filed by the local state administration (a plaintiff) may be supported by an environmental public organization (the decision of which is approved by the management) as a third person who files independent claims to the defendant in the form of an obligation of the latter to adopt a new decision to refuse the business entities in the allocation of land for placing their stationary trade objects.

After unification on October 3, 2017, the provisions of the Civil, Commercial Procedural Codes and the Code of Administrative Legal Proceeding, including on the legal status of third persons, the problems were eliminated which were not determined by certain peculiarities of the considered cases and created unjustified artificial obstacles for unifying the practice of the process at considering various categories of cases ${ }^{35}$. However, the concepts of "parties", "third persons" are currently defined

\footnotetext{
${ }^{33}$ Топор I. В. Поняття та види учасників адміністративного судочинства: проблеми теорії. Актуальні проблеми держави і права. 2011. Вип. 58. С. 265-266.

${ }^{34}$ Бевзенко В. М. Інститут процесуальної співучасті в адміністративному судочинстві України: сутність та правове регулювання. Держава і право. 2010. № 47. С. 225.

${ }^{35}$ Смітюх А. Треті особи в адміністративному судочинстві: особливості статусу. Юридичний радник. 2008. № 1. С. 86.
} 
in the CAP only in a descriptive way, with the consolidation of key types of thought structures, on which the process of reflection on the studied object is based. The parties are persons taking part in the case on their own behalf and in order to protect their own rights and interests, the dispute between them about the true nature and content of subjective rights and obligations is resolved by the court. According to the CAP, the parties include the plaintiff and the defendant. As it is clearly emphasized in scientific literature, taking into account the content of procedural functions performed during the administrative proceedings, two types of subjects can be distinguished: those who defend the claims, and those who defend themselves against such claims ${ }^{36}$. The parties conduct the process on their own behalf, they are subject to court costs, the court decision is made in their names and the decision is fully applicable to them. Participation of a party or a third person in the process is also ensured through representation of their interests by the procedural representative. In case of withdrawal or substitution of the party or the third person in disputable relations, the court allows replacing of the party or the third person at any stage of administrative process with the legal successor. All actions committed in the process before the legal successor's entry are binding for him to the extent that they would be binding for the person who was replaced by him $^{37}$.

Based on the principle of administrative procedural law dispositiveness, appealing to the court for protection of their violated or disputed rights is the prerogative of an exclusively linked material-legal and procedural-legal person (a plaintiff) or a prosecutor who is authorized to file claims in the interests of a collegial public administration subject ${ }^{38}$. For example, according to clause 30 of Part 1 of Article 43 of the Law of Ukraine "On Local Self-Government" on May 21, 1997, the issues are resolved exclusively at the plenary sessions of the district and regional council regarding the adoption of decisions on appeals to the court on recognition of unlawful acts of local executive bodies, enterprises, institutions and organizations restricting the rights of territorial communities in the area of their common interests, as well as the powers

\footnotetext{
36 Романченко Є. Ю. Виключні права суб'єктів процесуальних функцій в адміністративному судочинстві України. Наук. вісник Ужгородського нац-го ун-ту. Серія Право. 2014. Вип. 26. С. 166.

${ }^{37}$ Бречко А. В. Особливості правового положення сторін в адміністративному судочинстві. Форум права. 2009. № 1. С. 79-80.

${ }^{38}$ Бречко А. В. Особливості правового положення сторін в адміністративному судочинстві. Форум права. 2009. № 1. С. 80.
} 
of regional, district councils and their bodies. Part 3 of Article 69 of the Law of Ukraine "On the Election of the President of Ukraine" on March 5,1999 stipulates that a public organization has the right to file a decision about refusal to grant it permission to have official observers at the presidential elections in Ukraine to the court.

The subject studied by us in the administrative process, as a plaintiff, is a person in defense of whose rights, freedoms and interests a claim has been filed before the administrative court, including the subject of authority, for execution of powers of which a claim has been filed in the administrative court. Such persons are united by defending of claims, which is the main content of functions of these subjects. We should consider that the right to an administrative claim in its structure is ambiguous and consists of two essences: material-legal and procedurallegal $^{39}$. Procedural-legal form is reflected in the right to present an administrative claim to a court - a claim to the court on the protection of rights, and the material-legal part is the right to accept such claim and to satisfy the legal requirements of the plaintiff to the defendant ${ }^{40}$.

Taking into account the provisions of Article 19, 47 of the CAP, a collegial public administration subject, as a plaintiff in the administrative process, acts only in cases expressly provided by law. It may choose another subject of authority as the defendant as well as a natural person or legal entity of private law. The collective public administration subject acts in court only through a representative, because each individual member of the collegial subject does not acquire the procedural and legal status of the party to the case.

Considering the nature of collegiality as the principle of management involves administration of a group of persons (collegium), each of whom bears personal responsibility for a particular area of activity ${ }^{41}$, the rights of the plaintiff in relation to the power of legal energy and responsibility exceed each individual public administration subject acting alone, on the principle of undivided authority. The plurality of individuals within the collegial public administration subject, in otherwise equal conditions (i.e.,

\footnotetext{
${ }^{39}$ Науково-практичний коментар до Кодексу адміністративного судочинства України / за заг. ред. С. В. Ківалова, О. І. Харитонової. Х. : ТОВ “Одисей”, 2005. С. 246.

${ }^{40}$ Бречко А. В. Адміністративний позов як форма захисту прав, свобод та інтересів у сфері публічноправових відносин. Актуальні проблеми державного управління. 2009. № 2. С. 367.

41 Крысанов А. В. Конституционно-правовая ответственность выборных и должностных лиц федеральных органов государственной власти: дис. канд. юрид. наук : спец. 12.00.02. Челябинск, 2014. C. 142 .
} 
professionalism and spirituality of its members) affects positively the quality of its decisions, as well as the balance and justification of actions in the court proceeding. A judge will deal not only with the legal position of the majority of the collegial public administration subject, but also with the individual opinions of its members, whose reflections on the subject of compliance with law and legislation requires a systematic comparison of all these factors. This feature of the categories of cases involving such collegial subject may mathematically require creative legal energy from more than one judge, which accordingly raises the question about collegiality of judicial consideration of claims and objections to claims involving a collegial public administration subject, so that the decision of the administrative court becomes an embodiment of uncontested justice by the parties to the case or other persons and caused immutable trust in the court. After all, what our society calls the law is the result of the process of court decisions, which allows solving certain contradictions. The best ideas in which these decisions are embodied are of great significance exceeding the facts of specific disputes they solve $e^{42}$. One should imagine that the decision (actions) of such subject is indeed progressive and complex in content, for example, the National Commission on Securities and the Stock Market (hereinafter referred to as the NCSSM), in accordance with Article 19 of the CAP, appeals to the court with the claim to the Cabinet of Ministers of Ukraine (CMU) and/or some regional councils, as for removing obstacles to implementing its decision on joint investment, taking into account the trends of the financial market development in the short, medium and long term, as well as during a special period, may contain a basis that, during its unfolding and consideration in court, combined with the individual positions of the members of the NCSSM and all other evidence in the case, will be so complex that it will be impossible to evaluate it using mental resources of one judge only, even provided that experts, specialists (Articles 68, 70 CAP, respectively) and others are involved.

Not only the plaintiff has a legal interest in the administrative process, for whom it is both in obtaining the benefit that the decision of the administrative court on satisfaction of the claim will bring to him (material-legal interest) and in making the corresponding decision on

\footnotetext{
${ }^{42}$ Hoeflich M. H., Deutsch J. G. Judicial Legitimacy and the Disinterested Judge. Hofstra Law Review. 1978. Vol. 6. P. 749.
} 
satisfaction of the claim (procedural interest). A defendant has a legal interest as well, but it is opposite in content, for whom the material-legal interest consists in establishing the absence of any legal obligations to the plaintiff by an administrative court decision, and procedural - in making a decision to refuse in a claim ${ }^{43}$.

In the status of the defendant, a collegial public administration subject in administrative proceedings is the subject of authority, to which the plaintiff's claim is addressed. A defendant is a subject whose functions consist in protecting from claims in administrative proceedings. Such functions can be performed by third persons who do not appeal with independent claims, their representatives ${ }^{44}$. The state body and/or local self-government bodies bear responsibility for the decisions, actions or inaction that are the consequence of functioning of the collegial body ${ }^{46}$.

From the defendant's status of the collegial public administration subject in administrative proceedings after the court decision on satisfaction of the claim remains its key quality, namely: responsibility for the consequences of their actions based on a valid court decision subject to execution. However, scientists have emphasized for a long time that there is also a growing number of cases of public neglect of decisions made in relation to collective subjects of authority (local councils, executive committees of local councils, etc.). According to the CAP, punishment for such collegial body behavior is borne by its head. However, he has no and can not have legal levers of influence on the rest of members of this body. Under such conditions, the head is requested to provide the right to execute a court decision solely, if the collegial body did not do so within the period established by law or by $\operatorname{court}^{47}$. In connection with it, O. M. Paseniuk's suggestion is fully justified about the fact that a separate law on the procedure for executing court orders in cases concerning collegial decisions, actions or inaction of subjects of

\footnotetext{
43 Бречко А. В. Особливості правового положення сторін в адміністративному судочинстві. Форум права. 2009. № 1. С. 80.

44 Романченко Є. Ю. Виключні права суб'єктів процесуальних функцій в адміністративному судочинстві України. Наук. вісник Ужгородського нац-го ун-ту. Серія Право. 2014. Вип. 26. С. 166.

45 Матвійчук В. К., Хар І. О. Науково-практичний коментар до Кодексу адміністративного судочинства України. В 2-х тт. Том 1. / За заг. ред. В. К. Матвійчука. К. : КНТ, 2007. С. 123.

${ }^{46}$ Петришина М. Д. Суб'єкти владних повноважень як адміністративні позивачі в адміністративному процесі України. Юридичний науковий електронний журнал. 2017. № 6. С. 226.

${ }^{47}$ Компанієць I. М., Чиркін А. С. Деякі проблеми розвитку адміністративного судочинства в Україні. Теорія і практика правознавства. 2011. № 1. С. 6.
} 
authority should be adopted ${ }^{48}$, or the current Law of Ukraine "On Enforcement Proceedings" on June 2, 2016 should be added by relevant provisions, which does not contain at the moment any rules suitable for taking into account the specifics of implementation of the decisions of the administrative court by collegial public administration subjects. There are no similar provisions in section IV "Procedural issues related to execution of court decisions in administrative cases" of the CAP. Without adoption of these rules, the negative legal consequences for the defendant of the collegial public administration subject in administrative proceedings will be illusory, since the decisions will remain unfulfilled, and collegiality, as an effective democratic way of public administration, will be perceived by citizens only as a distortion of state responsibility, its deformation, which leads only to delays and losses ${ }^{49}$. The unfolding of such cultivation of collegial perception of citizenship as a harmful approach to public administration is a potentially good basis for the emergence of antidemocratic intentions based on the idea of a public resource management of one strong leader acting on the principle of sole command. Extrapolation of such approach to perception of the organizational principle priority in public administration at the level of collective/national consciousness provides its further transformation into stable antidemocratic tendencies that do not provide social progress by their nature and which our nation has tried to eliminate since the late 80 's of the $20^{\text {th }}$ century based on examples of the best social and legal practices of highly developed countries in the West and the East. In fact, it is important at present that administrative proceedings would be able to show finally its effect not only to individual civil servants but also to their work as a whole within a collegial public administration subject, without making an impression of the personal irresponsibility of each member of such subject. At the beginning of the $20^{\text {th }}$ century, O. S. Alekseyev successfully determined that the collegial public administration subject is a joint whole of its members, the highest governmental board (public administration), united by general political principles and designed to perform government functions (public administration) within the law and in accordance with these principles. He also emphasized that such

\footnotetext{
48 Пасенюк О. М. Адміністративне судочинство: стан та напрямки розвитку. Вісник Вищого адміністративного суду України. 2011. № 3. С. 7.

49 Ореховский А. И. Философия Ответственности. Методологический, концептуальнотеоретический, правовой, аналитико-прогностический аспекты. М.: Алгоритм, 2015. С. 11, 22.
} 
institution as a join homogeneous whole, united by general political principles, is an institution of the law-governed state and an indispensable condition for the constitutional order ${ }^{50}$, in which courts should restore the violated right by obliging a subject of authority, including a collegial body, to make a decision on the possibility, if refusal is considered unlawful, and other grounds for refusal are not provided (the ECHR judgment in the case Olsson v. Sweden on March 24, 1988) ${ }^{51}$.

As a party to a case, a collegial public administration subject may also act as a co-plaintiff or co-defendant in the administrative process. Procedural joint participation in administrative legal proceedings is a special procedural institution arising from uniform legal relations if the rights, freedoms, interests or obligations of participants in administrative proceedings do not exclude each other, the application of which ensures the exclusion of cases of making opposite decisions on similar claims. The actual presence of this institute in administrative proceedings follows from the norms of the CAP of Ukraine, which, however, do not have provisions yet on the detailed procedure for use of procedural joint participation with the definition of procedural status peculiarities ${ }^{52}$. As regulated by the rules of administrative procedural legislation participation in the administrative case of two or more plaintiffs or defendants, it can be active (active), inactive (passive) and mixed ${ }^{53}$. As participation in the administrative case of two or more plaintiffs or defendants is regulated by norms of administrative procedural legislation, it can be acting (active), non-acting (passive) and mixed ${ }^{54}$. Such options of procedural joint participation (plurality, collectivity of the parties) ${ }^{55}$ allow filing of collective claims or prosecuting several defendants at the same time. For example, the claim of local state administration on the motives of national security and public order provision to the political

\footnotetext{
50 Алексеев А. С. Безответственность монарха и ответственность правительства. М.: Типография т -ва И. Д. Сытина, 1907. С. 25-26.

51 Рішення у справі «Олссон проти Швеції» : Європейський суд з прав людини від 24.03.1998 p. (скарга №10465/83). URL: http://europeancourt.ru/resheniya-evropejskogo-suda-na-russkom-yazyke/olssonprotiv-shvecii-postanovlenie-evropejskogo-suda/

52 Сало А. Особливості інституту процесуальної співучасті в адміністративному судочинстві України. Вісник Нац-го ун-ту «Львівська політехніка». Серія: Юридичні науки. 2017. № 865. С. 329.

53 Бевзенко В. М. Інститут процесуальної співучасті в адміністративному судочинстві України: сутність та правове регулювання. Держава і право. 2010. № 47. С. 227.

54 Бевзенко В. М. Інститут процесуальної співучасті в адміністративному судочинстві України: сутність та правове регулювання. Держава і право. 2010. № 47. С. 227.

55 Рафальська О. В. Поняття «процесуальна співучасть» в адміністративному судочинстві України. Право і суспільство. 2017. № 2. С. 119.
} 
party, its deputy faction and public organizations joint in their actions with a collegial decision-making principle (directorate, board, meetings, etc.) on the restriction of the right to peaceful assembly by prohibiting them to use loudspeakers, motor vehicles, posters, install tents, scenes, sheds at a specific time in a specific location.

The concepts of the third persons (from initial nominations in Latin: "litis denunciation", "laudatio auctoris") are found at the level of legal doctrine. They are defined as participants in the administrative process, which enter or are involved in it at any time until its completion, in order to realize their own specific interests, which are completely or partially different from the interests of the parties ${ }^{56}$. Participation of a third person contributes to a comprehensive consideration of the case, the gathering of more evidences, the correct resolution of the case, helps to avoid situations where in legal cases which are typical in content opposite court decisions are adopted ${ }^{57}$. Part 1 of Article 49 of the CAP, third persons who appeal independent claims regarding the subject matter of the dispute may enter into the case before the completion of preparatory proceedings or before the beginning of the first court hearing, if the case is considered under the procedure of simplified proceedings, bringing a claim to one or more parties. The satisfaction of such persons' claim should exclude satisfaction of the claims of the plaintiff to the defendant completely or partially. In case of the entry of third persons who file independent claims on subject matter of the dispute, the consideration begins from the outset of the administrative case by the petition of the party to a case.

In accordance with Part 2 of Article 49 of the CAP, third persons who do not declare independent claims on the subject matter of the dispute, may enter a case on the plaintiff's side or the defendant's side before the end of the preparatory meeting or before the beginning of the first court hearing, if the case is considered under the procedure of the simplified proceedings, in case when the decision in the case may affect their rights, freedoms, interests or obligations. They can be involved in participation to the case upon the request of the participants to the case as well. If an administrative court, making a decision on the issue of the opening of proceedings or in the preparation of a case for consideration,

\footnotetext{
${ }^{56}$ Рябченко Я. Участь третіх осіб під час оскарження нормативно-правових актів. Вісник НАПрНУ. 2013. № 3. С. 152.

${ }^{57}$ Кодекс адміністративного судочинства України : у 2 т. : [науково-практичний коментар / за заг. ред. Р. О. Куйбіди]. К. Книга для бізнесу, 2007. Т. 1. 2007. С. 232.
} 
determines that a court decision may affect the rights and obligations of persons who are not parties to the case, the court shall involve such persons in participation in the case as third persons who do not declare independent claims regarding the subject matter of the dispute. The introduction of third persons who do not declare independent claims regarding the subject matter of the dispute does not result in consideration of the administrative case from the outset.

Part 3 of Article 49, taking into account the social importance of powers of such collegial public administration subject as the National Agency for the Prevention of Corruption, specifically emphasizes the possibility of involving it as a third party which does not file independent claims on the subject matter of the dispute on the plaintiff's side in cases involving the use of the head or the employer or creation a threat by him in taking negative measures of influence to the plaintiff (dismissal, coercion to dismissal, disciplinary action, transfer, attestation, change in working conditions, refusal to appoint to a higher position, reduction in salary, etc.) in connection with his notification or his family member about a violation of the requirements of the Law of Ukraine "On Prevention of Corruption" by another person.

The essence of the legal capacity of a collegial public administration subject in administrative proceedings as a plaintiff, a defendant or a third person is determined by the CAP through its rights and obligations. Among the rights of the participants in the administrative process are mentioned the legal opportunities: 1) to familiarize with the materials of the case, to make extracts from them, copies, to receive copies of court decisions; 2) to submit evidences; to participate in court sessions, unless otherwise specified by law; to participate in the study of evidence; ask questions to other participants to the case, as well as witnesses, experts, specialists; 3) to submit applications and petitions, provide explanations to the court, present their arguments, considerations regarding issues that arise during the judicial consideration, as well as objections to statements, petitions, arguments and considerations of other persons; 4) to familiarize with the protocol of the court session, the record of the court session by technical means, make copies of them, submit written comments about their incorrectness or incompleteness; 5) to appeal against court decisions in cases determined by law; 6) at own expenses, to order and obtain certified copies of documents and extracts from them; 7) to use other procedural rights determined by law. It is noted that the parties to the case are obliged: 1) to show respect for the court and other participants in the 
court process; 2) to contribute to timely, comprehensive, complete and objective establishment of all circumstances of the case; 3) to appear in a court session upon the call of a court, if such appearance is recognized by the court as compulsory; 4) to submit the evidence available to them in the order and within the terms established by law or court, not to conceal evidence; 5) to provide the court with complete and reliable explanations of the issues raised by the court, as well as the participants in the case in court; 6) to execute procedural actions in accordance with the terms established by law or by court; 7) to perform other procedural duties, determined by law or by court (Part 3-5 of Article 44).

In practice, the implementation of these procedural powers faces the problems of interpretation of possibility and/or the need to commit or refrain from actions in relation to particular circumstances of the case by the court and participants, taking into account the principles of administrative legal proceedings. The Supreme Court unification of the implementation of administrative law contributes to ensuring the full use of procedural rights and proper performance of obligation by collegial public administration subjects as well as any other type of participants in the administrative process, according to Part 2 of Art. 36 of the Law of Ukraine "On the Judicial System and Status of Judges" on June 2, 2016, which, among other things, takes into account the relevant practice of the ECHR, for example, in relation to the exclusive right of the parties to evaluate the compliance of materials provided by the witness with his comments; providing opportunities for expressing opinions on each document in the case, including those received by the court in their petition (Pellegrini v. Italy, $\S 45$ ); in relation to the right to competitive proceedings: the party to the case must be able to familiarize with evidence in the court and comment on their existence, content and authenticity in due form within the determined time (Case Kramer and Others v. the Czech Republic, § 42; Immeubles Groupe Kosser v. France, $\S 26)^{58} 59$.

In general, the above-described specificity of the material legal capacity of the collegial public administration subject as a party to a case in administrative proceedings is nominated by the word "procedural",

\footnotetext{
58 Посібник зі статті 6 право на справедливий суд (цивільна частина) Дослідницького підрозділу Свропейського Суду з прав людини. URL: https://www.echr.coe.int/Documents/Guide_Art_6_UKR.pdf

${ }^{59}$ Корецький I. О. Принцип змагальності сторін в адміністративному судочинстві: дис. канд. юрид. наук : спец. 12.00.07. К., 2017. С. 169-188.
} 
"judicial" ${ }^{60}$ or other similar to it (in particular, Article 43 of the CAP). Therefore, Articles 44, 47, 49, 51, 53, 54 of the CAP contain a list of powers (rights and obligations) of this kind of subject. This detailing of its administrative procedural legal capacity is the key to the corresponding legal status, along with the principles of administrative legal proceedings (Articles 2, 5-18 of the CAP), responsibility (Chapter 9 of the CAP "Measures of Procedural Coercion", Article 382 of the CAP "Judicial Control over the Execution of Judicial Decisions in Administrative Cases"; Article 185-3 "Manifestation of Disrespect to a Court or Constitutional Court of Ukraine", Article 185-6 "Failure to take measures for a separate court order" of the Code of Ukraine on Administrative Offences on December 7, 1984, № 8073-X) etc.

The ability to act in a case through a representative becomes the next important element of the procedural legal status of any participant in the administrative process, including those studied by us. This follows from the objective reason that they have the legal possibilities provided by law for defending claims in person as a plaintiff or a third person, as well as through intermediation of other persons - representatives, third persons and other authorized subjects, in accordance with the CAP. The legal status of representatives as subjects of the administrative process is a complex category, which includes the tasks and functions, rights, obligations and responsibilities of representatives specified by administrative law. Among the tasks of the representative, determining his legal status are the following: 1) counseling on the opportunity to apply the law by a person; 2) the protection of rights, freedoms and legitimate interests of a certain person in the administrative judicial process; representation of the client in the administrative court; 3) the promotion of the administration of justice and the maintenance of legitimacy; 4) increase of legal awareness and legal culture of population ${ }^{61}$. Representatives of collegial public administration subjects in administrative proceedings may be prosecutors or lawyers, as well as, in case of revision of legislation norms on administrative proceedings in relation to the right to represent and protect the interests of other persons

\footnotetext{
60 Сонюк О. В. Особливості участі невладних суб'єктів у правовідносинах адміністративного судочинства. Часопис Київського університету права. 2013. № 1. С. 149.

61 Лисенко Ю. О. Представництво в адміністративному процесі: автореф. дис. на здобуття наук. ступеня канд. юрид. наук : спец. 12.00.07 «Адміністративне право і процес; фінансове право; інформаційне право». Запоріжжя, 2018. С. 12.
} 
when considering administrative cases by non-advocates ${ }^{62}$, other persons admitted by the court.

Thus, unfolding the problem of conceptualization of the legal phenomenon such as "a collegial public administration subject as a party to a case in administrative proceedings", revealed that its theoretical comprehension and substantiation at the level of doctrine are taking place at present. At the same time, practical steps to resolve the issues of participation of such subject have been implemented since the entry into force of the CAP. The problem we have dealt with in this work is on the edge of administrative law, in terms of defining the concept of "a collegial public administration subject", and of the administrative process, in terms of attribution of the latter to the participants in the case by way of administrative proceedings. The positivist approach to law provides operating of the legal lexis of "legal status" for the complete description of the formal-legal substance of the concept "a collegial public administration subject as a party to a case in administrative proceedings". At the same time, within the natural legal approach of legal thinking, these thoughts are transformed into essence of the legal phenomenon, denominated by the corresponding complex expression. In total, "a collegial public administration subject as a party to administrative proceedings", being an institution of state and municipal administration, including represented by the subjects of private law with public authority, is conceptualized through the following features: 1) public authorities, including those delegated to private law entities, including within the framework of public-private partnership forms ${ }^{63}$ etc.; 2) equality and absence of hierarchical relations (official subordination) between officials, as well as between them and the head (manager) of this subject; 3) the method of social objectification: group/collective organizational and legal activity and the form (principle) of organizational structure that is adequate to it during the development and adoption of decisions reflecting their absolute, or predominantly common/agreed upon all essential issues, will, and the joint legal, moral and/or political responsibility for the consequences of their actions, which are always the consequences of a previously made decision (including oral, not made on paper, and which is

\footnotetext{
${ }^{62}$ Чудик Н. Участь адвоката в адміністративному процесі. Актуальні проблеми правознавства. 2017. Вип. 4. С. 158.

${ }^{63}$ Брайловський І. А. Державно-приватне партнерство: методологія, теорія, механізми розвитку: дис. док. економ. наук : спец. 08.00.01. Донецьк, 2014. 462 с.

${ }_{64}$ Винницький Б., Лендьел М., Онищук Б., Сегварі П. Досвід та перспективи впровадження державно-приватних партнерств в Україні та за кордоном. К.: «К.І.С.», 2008. 55 с.
} 
objectified in the acts) at the level of common consciousness. The relevant special (public power) legal status of members of the collegial public administration subject as a party to administrative proceedings determined by their membership in this body; 4) administrative procedural legal capacity, and, more precisely, its correlation with the collegial way of acts and responsibilities of the subject, its realization with the obligatory participation of a sole representative.

The legal status nature of a "collegial public administration subject as a party to a case in an administrative proceeding" by itself is multistructural and consists of at least four legal statuses: 1) of the subject of public administration; 2) joint collective work, in fact collegiality; 3) a legal entity or a subject derived from a legal entity; 4) a participant to a court case within the limits specified by the administrative-procedural law.

In all cases of possible involvement of a collegial public administration body by a judge as a subject facilitating the administrative justice or his participation as a party or a third person to a case, this subject does not perform law enforcement, but acts on the principles of dispositiveness with all other subjects of the administrative process.

\section{REFERENCES}

1. Лившиц Р. 3. Теория права. Учебник М.: Издательство БЕК, 1994. 224 c.

2. Свропейські орієнтири адміністративного реформування в Україні : монографія / за заг. ред. В. Д. Бакуменка, В. М. Князєва. К. : Вид-во НАДУ, 2005. 172 с.

3. Довіра до суду та імідж судової влади: які вони сьогодні? / дата звернення 10.05.2018. URL : https://censor.net.ua/blogs/3065355/ dovra_do_sudu

4. Іванченко О. Система критеріїв оцінювання ефективності діяльності судів під час надання судових послуг. Підприємництво, господарство і право. 2017. № 11. С. 222-225.

5. Мацелик Т. О. Суб'єкти адміністративного права: поняття та система: монографія. Ірпінь: Вид-во Нац. ун-ту ДПСУ, 2013. 342 с.

6. Алексеев С. С. Теория права. М.: Издательство БЕК, 1995. 320 с.

7. Загальна теорія права: підручник / За заг. ред. М.І. Козюбри. К.: Ваіте, 2015. 392 c.

8. Máynez E. G. Introduccion al estudio del derecho : libro didáctico. - 53 Edición. México : Editorial Porrua, 2002. 466 c. 
9. Бевзенко В. М., Панова Г. В. Сутність та підстави втручання адміністративного суду у розсуд суб'єкта публічної адміністрації: монографія. К. : ВД «Дакор», 2018. 232 с.

10. Панейко Ю. Л. Наука адміністрації й адміністративного права (загальна частина). Т. 1. Аугсбург, 1949. 115 с.

11. Колпаков В. К. Адміністративно-правові відносини: поняття і види. Юридичний науковий електронний журнал. 2013. № 1. С. 101-104.

12. Петров А. В., Баукен А. А. Теория государства и права: учебное пособие. Челябинск : Издат. центр ЮУрГУ, 2014. 238 с.

13. Алексеев С.С. Общая теория права : учеб. 2-е изд., перераб.и доп. М. : ТК Велби, Изд-во Проспект, 2008. 576 с.

14. Сремєєв Д.В., Менсітов О.С. Деякі питання генезису судового оскарження рішень, дій чи бездіяльності органів внутрішніх справ України. Ученые записки ТНУ им. В.И. Вернадского: Серия «Юридические науки». 2011. Том 24 (63). № 1. С. 188-194.

15. Константий О. В. Захист прав фізичних та юридичних осіб в адміністративному судочинстві: проблеми теорії i практики: дис. док. юрид. наук : спец. 12.00.07. Х., 2015. 415 с.

16. Шатило О.А. Публічне адміністрування: опорний конспект лекцій. Житомир: ЖДТУ, 2014. 51 с.

17. Казакевич П. В. Організаційно-правове співробітництво органів судової влади України та Ради Європи: дис. канд. юрид. Наук : спец. 12.00.10. Х., 2017. 224 с.

18. Шайкенов Н.А. Правовое обеспечение интересов личности. Свердловск: Изд-во Урал. ун-та, 1990. 200 с.

19. Галунько В., Діхтієвський П., Кузьменко О., Стеценко С. та ін. Адміністративне право України. Повний курс: Підручник. Херсон: Олді-плюс, 2018. 446 с.

20. Давитнидзе И. Л. Коллегиальность и единоначалие в советском государственном управлении. М. : «Знание», 1974. 64 с.

21. Авер'янов В. Понятійно-термінологічні новели кодексу адміністративного судочинства України: дискусійні проблеми. Право України. 2011. № 4. С. 12-38.

22. Явич Л. С. Общая теория права. Л.: Изд-во ЛГУ, 1976. 286 с.

23. Авер'янов В. Б. Адміністративне право України. Академічний курс : в двох томах. К.: ТОВ «Видавництво «Юридична думка», 2007. Том 1: Загальна частина: підручник / гол. ред. кол. : Авер'янов В. Б. 592 с. 
24. Самагальська Ю.Я. Інспекційні повноваження та правові основи їх реалізації. Вісник Львівського ун-ту. Серія юридична. 2012. Вип. 56. С. 209-214

25. Українське право: Новий Кодекс адміністративного судочинства: позиція суддів Верховного Суду з проблемних питань / дата звернення 29.01.2018. URL: http://www.vaas.gov.ua/news/ukra $\%$ D1\%97nske-pravo-novij-kodeks-administrativnogo-sudochinstvapoziciya-suddiv-verxovnogo-sudu-z-problemnix-pitan/

26. Ведєрніков Ю. А., Шкарупа В. К. Адміністративне право України: навчальний посібник. К. : Центр навчальної літератури, 2005. $336 \mathrm{c}$.

27. Бевзенко В.М. Суб'єкти владних повноважень у адміністративному процесі України. Журнал східноєвропейського права. 2013. № 1. С. 12-18.

28. Топор I. В. Поняття та види учасників адміністративного судочинства: проблеми теорії. Актуальні проблеми держави і права. 2011. Вип. 58. С. 264-271.

29. Бевзенко В. М. Інститут процесуальної співучасті в адміністративному судочинстві України: сутність та правове регулювання. Держава і право. 2010. № 47. С. 222-227.

30. Калюжний Р.А., Кушнір І.П. Правове забезпечення взаємодії публічної адміністрації у прикордонній сфері : монографія. К. : «МП Леся», 2015. 224 c.

31. Смітюх А. Треті особи в адміністративному судочинстві: особливості статусу. Юридичний радник. 2008. № 1. С. 83-86.

32. Романченко Є. Ю. Виключні права суб'єктів процесуальних функцій в адміністративному судочинстві України. Наук. вісник Ужгородського нац-го ун-ту. Серія Право. 2014. Вип. 26. С. 166-169.

33. Бречко А. В. Особливості правового положення сторін в адміністративному судочинстві. Форум права. 2009. № 1. С. 78-82.

34. Науково-практичний коментар до Кодексу адміністративного судочинства України / за заг. ред. С. В. Ківалова, О. І. Харитонової. Х. : ТОВ “Одисей”, 2005. 787 с.

35. Бречко А. В. Адміністративний позов як форма захисту прав, свобод та інтересів у сфері публічно-правових відносин. Актуальні проблеми державного управління. 2009. № 2. С. 366-372.

36. Крысанов А. В. Конституционно-правовая ответственность выборных и должностных лиц федеральных органов 
государственной власти: дис. канд. юрид. наук : спец. 12.00.02. Челябинск, 2014. 196 с.

37. Hoeflich M. H., Deutsch J. G. Judicial Legitimacy and the Disinterested Judge. Hofstra Law Review. 1978. Vol. 6. p. 749-754.

38. Матвійчук В. К., Хар I. О. Науково-практичний коментар до Кодексу адміністративного судочинства України. В 2-х тт. Том 1. / За заг. ред. В. К. Матвійчука. К. : КНТ, 2007.788 с.

39. Петришина М. Д. Суб'єкти владних повноважень як адміністративні позивачі в адміністративному процесі України. Юридичний науковий електронний журнал. 2017. № 6. С. 223-226.

40. Городовенко В. В., Макаренков О. Л., Сантуш М. М. О., Сінєльник Р. В. Судові та правоохоронні органи України. Запоріжжя: ЗНУ, 2018. $240 \mathrm{c.}$

41. Компанієць I. М., Чиркін А. С. Деякі проблеми розвитку адміністративного судочинства в Україні. Теорія і практика правознавства. 2011. № 1. С. 1-9.

42. Пасенюк О. М. Адміністративне судочинство: стан та напрямки розвитку. Вісник Вищого адміністративного суду України. 2011. № 3. С. 3-12.

43. Ореховский А. И. Философия Ответственности. Методологический, концептуально-теоретический, правовой, аналитико-прогностический аспекты. М.: Алгоритм, 2015, 288 с.

44. Алексеев А. С. Безответственность монарха и ответственность правительства. М.: Типография т -ва И. Д. Сытина, 1907. 70 с.

45. Рішення у справі «Олссон проти Швеції» : Свропейський суд 3 прав людини від 24.03.1998 р. (скарга №10465/83). URL: http://europeancourt.ru/resheniya-evropejskogo-suda-na-russkomyazyke/olsson-protiv-shvecii-postanovlenie-evropejskogo-suda/

46. Сало А. Особливості інституту процесуальної співучасті в адміністративному судочинстві України. Вісник Нац-го ун-ту «Львівська політехніка». Серія: Юридичні науки. 2017. № 865. C. 325-331.

47. Рафальська О. В. Поняття «процесуальна співучасть» в адміністративному судочинстві України. Право і суспільство. 2017. № 2. С. $118-122$.

48. Рябченко Я. Участь третіх осіб під час оскарження нормативно-правових актів. Вісник НАПрНУ. 2013. № 3. С. 151-156. 
49. Кодекс адміністративного судочинства України : у 2 т. : [науково-практичний коментар / за заг. ред. Р. О. Куйбіди]. К. Книга для бізнесу, 2007. Т. 1. 2007. 552 с.

50. Посібник зі статті 6 право на справедливий суд (цивільна частина) Дослідницького підрозділу Свропейського Суду з прав людини. URL: https://www.echr.coe.int/Documents/Guide_ Art_6_UKR.pdf

51. Корецький I. O. Принцип змагальності сторін в адміністративному судочинстві: дис. канд. юрид. наук : спец. 12.00.07. К., 2017. $223 \mathrm{c.}$

52. Сонюк О. В. Особливості участі невладних суб'єктів у правовідносинах адміністративного судочинства. Часопис Київського університету права. 2013. № 1. С. 149-153.

53. Лисенко Ю. О. Представництво в адміністративному процесі: автореф. дис. на здобуття наук. ступеня канд. юрид. наук : спец. 12.00.07 «Адміністративне право і процес; фінансове право; інформаційне право». Запоріжжя, 2018. 20 с.

54. Чудик Н. Участь адвоката в адміністративному процесі. Актуальні проблеми правознавства. 2017. Вип. 4. С. 153-158.

55. Брайловський I. А. Державно-приватне партнерство: методологія, теорія, механізми розвитку: дис. док. економ. наук : спец. 08.00.01. Донецьк, 2014. 462 с.

56. Винницький Б., Лендьел М., Онищук Б., Сегварі П. Досвід та перспективи впровадження державно-приватних партнерств в Україні та за кордоном. К.: «К.I.С.», 2008. 55 с.

\section{Information about the author: Tsvirkun Yu. I. Candidate of Juridical Sciences}

